\title{
Rancang Bangun Mekanisme Penendang Bola Berbasis Elektromagnetik untuk Robot Sepakbola Beroda R2C-Warrior
}

\author{
Yohanes Haryudanta D ${ }^{1}$, Fransiscus Dalu Setiaji², Gunawan Dewantoro ${ }^{3}$ \\ Program Studi Teknik Elektro, \\ Fakultas Teknik Elektronika dan Komputer, \\ Universitas Kristen Satya Wacana, Salatiga \\ 1612013004@student.uksw.edu, 2fdsetiaji@gmail.com, ${ }^{3}$ gunawan.dewantoro@staff.uksw.edu
}

\begin{abstract}
Ringkasan
Pada Kontes Robot Indonesia (KRI) 2017, diadakan sebuah kompetisi untuk divisi baru yaitu Kontes Robot Sepakbola Beroda Indonesia (KRSBI Beroda). Ini mendorong tim Robotics Research Center (R2C) Universitas Kristen Satya Wacana membuat suatu platform robot baru sehingga dapat diikutsertakan pada kompetisi tersebut. Layaknya seorang pemain sepakbola profesional, maka platform robot ini membutuhkan suatu mekanisme penendang bola sehingga robot dapat mencetak gol ke gawang lawan. Pada makalah ini, diusulkan sebuah mekanisme penendang bola yang menggunakan prinsip elektromagnetik. Mekanisme ini terdiri dari sebuah solenoid yang dicatu oleh tegangan maksimal 400V. Tegangan tersebut didapatkan dari sebuah baterai Li-Po 12V dengan kapasitas 2200mAh yang dinaikan tegangannya melalui sebuah $D C$ to $D C$ booster dan ditampung pada sebuah capacitor bank berkapasitas $2240 \mu \mathrm{F}$. Mekanisme ini dapat menendang bola dengan diameter $20 \mathrm{~cm}$ dan berat 400gr dengan laju maksimal bola sebesar $10,04 \mathrm{~m} / \mathrm{s}$.
\end{abstract}

Kata kunci: Solenoid, DC to DC booster, Penendang Bola, Robot Sepakbola

\section{Pendahuluan}

Dengan ikut sertanya tim R2C FTEK-UKSW dalam kegiatan tahunan KRI membuat pengembangan robot penting dilakukan untuk meningkatkan prestasi tim. Ditambahnya divisi KRSBI Beroda mengharuskan tim R2C membuat sebuah platform robot baru dengan sistem penendang bola yang mampu menendang bola berdiameter $20 \mathrm{~cm}$ dengan massa 400 gram serta ringkas dalam segi dimensi alat, sehingga memudahkan robot untuk bermanuver dan mencetak gol ke gawang lawan.

Pada makalah ini, akan dirancang sebuah sistem penendang bola berbasis elektromagnetik dengan menggunakan solenoid yang di dalamnya terdapat sebuah inti besi (plunger) yang dapat bergerak bebas. Solenoid dipilih karena dapat menghasilkan kekuatan tendang yang kuat dan dimensinya relatif kecil [1]. Kekuatan medan magnet yang menentukan kekuatan tendang tergantung pada besar arus yang mengalir pada solenoid [2]. Sistem serupa sudah pernah disampaikan pada The $4^{\text {th }}$ Symposium on Robot Soccer Competition 2016. Sistem tersebut menggunakan rangkaian DC to DC booster berbasis IC regulator tersaklar MAX1771 yang relatif sulit didapatkan di Indonesia[2]. IC MAX1771 sendiri merupakan IC pengontrol penaik tegangan (step-up switching controller) yang fungsi utamanya terbagi menjadi dua yaitu membangkitkan gelombang kotak dan mengatur 
tegangan keluaran dengan cara memvariasikan frekuensi gelombang kotak yang dibangkitkan.

Dalam makalah ini diusulkan sebuah sistem penendang dengan rangkaian $D C$ to $D C$ booster yang berbasis timer LM555 sebagai penghasil gelombang kotak dan opamp LM324 yang difungsikan untuk membatasi nilai tegangan yang akan disimpan di dalam sebuah capacitor bank. Hal tersebut dicapai dengan cara mengaktifkan atau menonaktifkan rangkaian $D C$ to $D C$ booster berdasarkan nilai tegangan pada capacitor bank. Tujuannya adalah agar pengguna dapat mengatur kekuatan tendang dari mekanisme ini sebelum pertandingan berlangsung. Kedua IC tersebut dipilih karena harganya murah dan mudah didapatkan di Indonesia dibandingkan IC MAX1771, sehingga mudah diganti jika rusak.

\section{Perancangan}

Mekanisme penendang bola pada makalah ini terdiri menjadi dua bagian utama, yaitu bagian mekanik dan bagian elektrik. Bagian elektrik sendiri dapat kembali dipecah menjadi empat bagian, yaitu bagian penaik tegangan, bagian pembatas tegangan, bagian pemicu tendangan dan bagian pengosong tegangan capacitor bank. Gambar 1 merupakan diagram kotak alat yang dibuat, kecuali bagian Algoritma Utama.

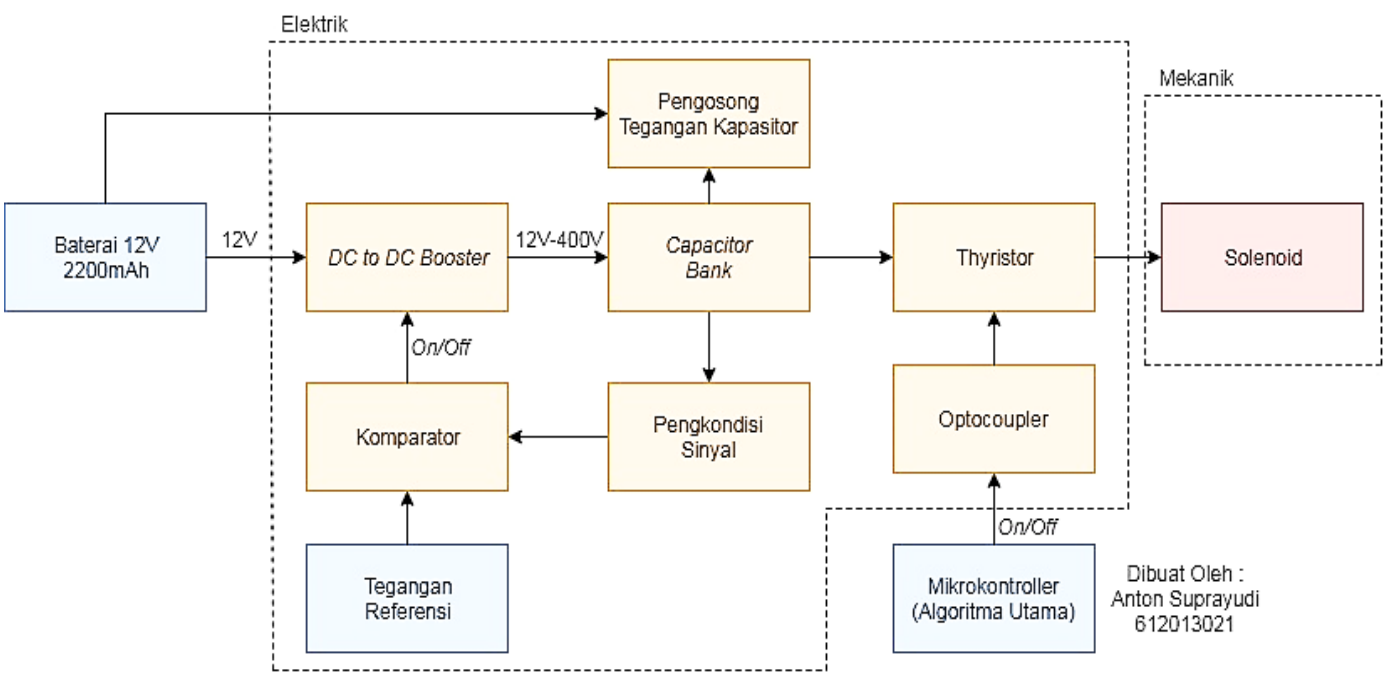

Gambar 1. Diagram kotak mekanisme penendang bola

\subsection{Perancangan Bagian Mekanik}

Gambar 2 menunjukkan mekanik utama alat yang terdiri dari sebuah solenoid yang ditopang rangka besi sehingga dapat dipasang pada bodi robot. Solenoid dibuat dari kawat enamel dengan diameter $0,8 \mathrm{~mm}$ dan dililitkan pada sebuah pipa PVC dengan diameter 1,25 inci. Solenoid yang direalisasikan memiliki panjang $11,5 \mathrm{~cm}$, diameter $3,1 \mathrm{~cm}$ dan resistansinya $7,4 \Omega$. Sedangkan plunger dibuat dari besi yang memiliki panjang $26 \mathrm{~cm}$ dan diameter $3 \mathrm{~cm}$. Digunakan juga shield berbahan besi dengan ketebalan $1 \mathrm{~mm}$ yang berbentuk tabung sehingga permukaan solenoid tidak langsung terpapar dengan lingkungan luar. Shielding ini juga diperlukan untuk memfokuskan medan magnet yang dihasilkan oleh solenoid[3]. 


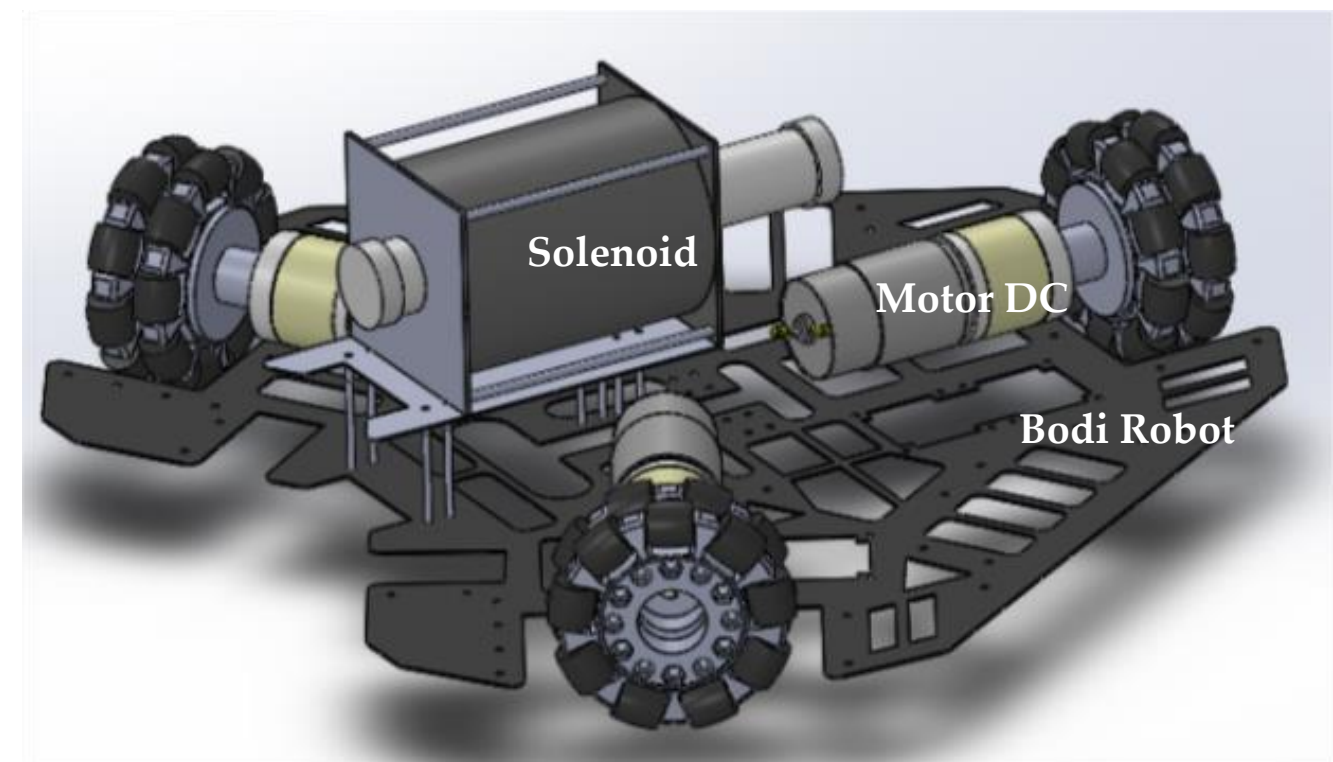

Gambar 2. Desain mekanik mekanisme penendang bola robot R2C Warrior

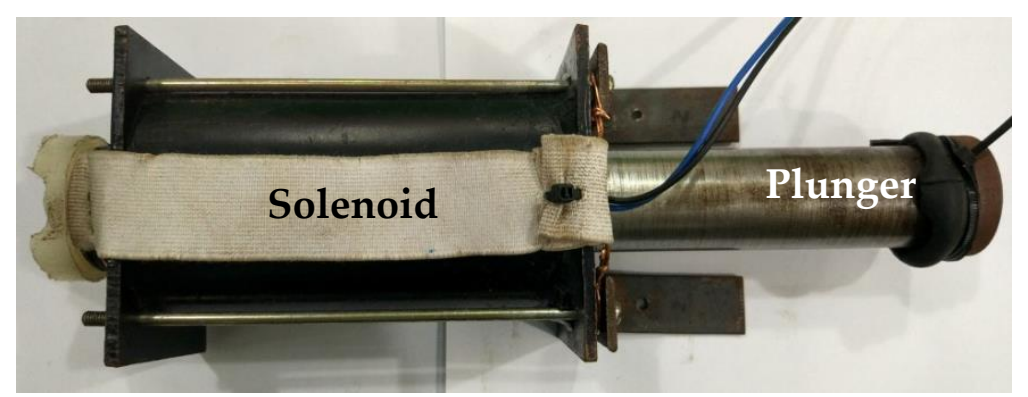

Gambar 3. Realisasi mekanik solenoid tampak atas

\subsection{Perancangan Bagian Elektrik}

Bagian elektrik alat akan dibagi menjadi empat bagian yaitu bagian: penaik tegangan, pembatas tegangan, pengendali tendangan dan pengosong tegangan.

\subsubsection{Rangkaian Penaik Tegangan (DC to DC booster)}

Rangkaian penaik tegangan $D C$ (Gambar 4) atau biasa disebut $D C$ to $D C$ booster adalah sebuah topologi catu daya yang dapat menghasilkan tegangan $D C$ keluaran yang lebih tinggi dibandingkan dengan tegangan masukan[4]. DC to DC booster termasuk tipe catu daya tersaklar karena transistor hanya mempunyai dua siklus yaitu "on" (saat MOSFET dalam kondisi triode) dan siklus "off" (saat MOSFET dalam kondisi cut-off).

Siklus tersebut diatur oleh sebuah pembangkit gelombang kotak yang direalisasikan menggunakan rangkaian astable berbasis LM555, dengan duty cycle 50\%. Periode gelombang kotak $(T)$ ditentukan berdasarkan nilai arus induktor $L_{1}$ yang akan tercapai selama MOSFET "on" yaitu $1 / 2 T$, yang dipilih sebesar $5 \mathrm{~A}$, yaitu nilai maksimal yang diperbolehkan. MOSFET yang digunakan adalah IRFP460 yang memiliki nilai $R_{\mathrm{DS}(\text { on) }}$ sebesar $0,27 \Omega[5]$. Dengan menganggap arus awal $L_{1}$ bernilai nol, maka nilai $T$ bisa ditentukan berdasarkan persamaan pengisian arus induktor sebagai berikut ini.

$$
i_{L 1}(T / 2)=5 A=\frac{V_{C C}}{R_{D S}(\text { on })}\left(1-e^{-\frac{T}{2} \frac{R_{D S(o n)}}{L_{1}}}\right)
$$


Didapatkan nilai $T=48,5 \mu$ s atau frekuensinya, $f=20,6 \mathrm{kHz}$. Rangkaian pembangkit gelombang kotak yang dibuat ditunjukkan Gambar 5, dirancang berdasarkan [6].

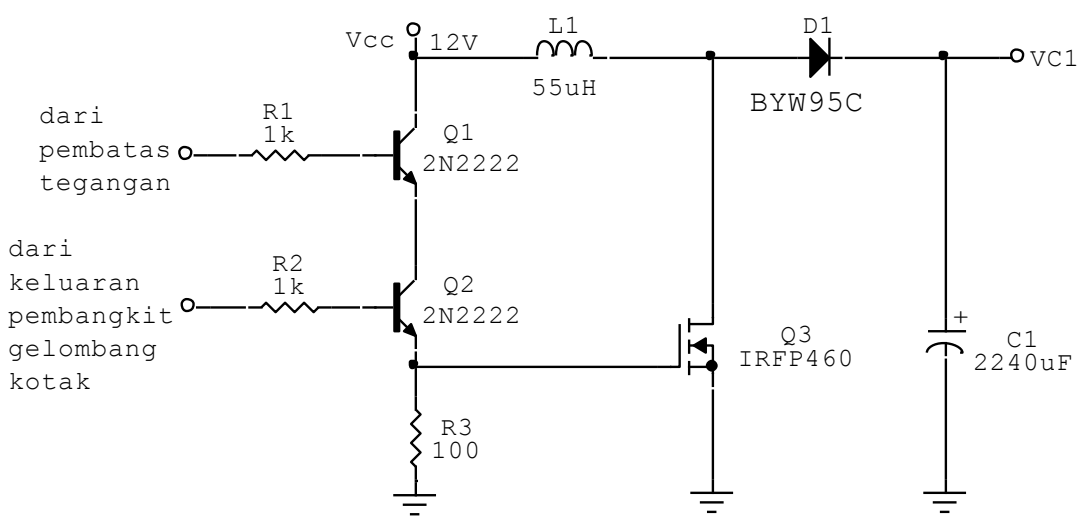

Gambar 4. Skema rangkaian penaik tegangan

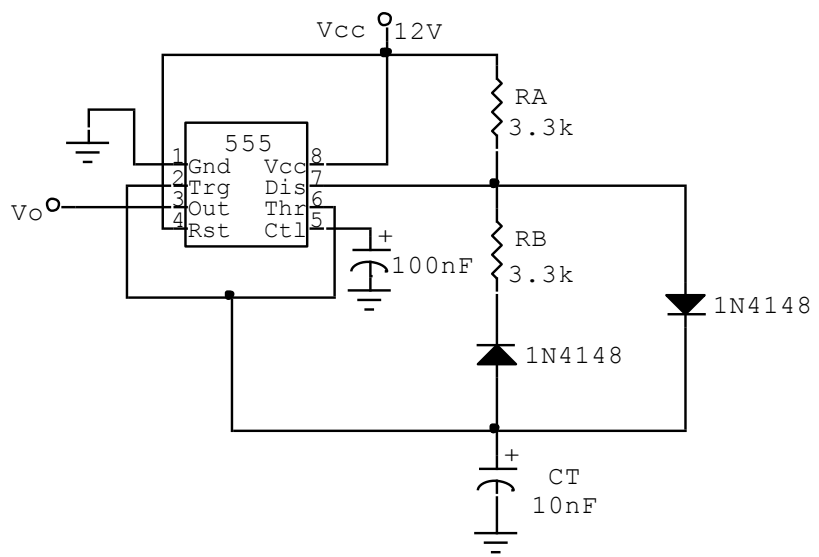

Gambar 5. Pembangkit gelombang kotak dengan Duty Cycle 50\%

Nilai $C_{1}$ ditentukan berdasarkan spesifikasi awal yang ditetapkan yaitu agar bola yang ditendang dapat melaju minimal $5 \mathrm{~m} / \mathrm{s}$, yang membutuhkan energi:

$$
E_{\mathrm{K}}=\frac{1}{2} \times 0,4 \times 5^{2}=5 \mathrm{~J}
$$

Namun karena rendahnya efisiensi dalam mengubah energi listrik menjadi energi kinetik yang dapat mencapai $5 \%$ saja [3], maka energi minimal yang harus disimpan dalam kapasitor adalah $W_{\mathrm{C} 1}=5 \mathrm{~J} / 0,05=100 \mathrm{~J}$. Tegangan maksimum kapasitor ditetapkan sebesar $400 \mathrm{~V}$, sesuai dengan batas aman dari kapasitor yang dipakai. Untuk dapat menyimpan energi sebesar itu pada tegangan $400 \mathrm{~V}$ maka nilai kapasitor $\mathrm{C}_{1}$ adalah:

$$
C_{1}=\frac{100 \mathrm{~J}}{0,5 \times(400 \mathrm{~V})^{2}}=1.250 \mu \mathrm{F}
$$

Namun demikian, untuk mengantisipasi jika terdapat penambahan kebutuhan energi (misalnya bila bola juga berotasi setelah ditendang) dan juga kehilangan energi yang belum diperhitungkan, maka digunakan kapasitor yang nilainya hampir dua kali lipat dari perhitungan (3) yaitu sebesar $2240 \mu \mathrm{F}$. 


\subsubsection{Rangkaian Pembatas Tegangan}

Rangkaian pembatas tegangan (Gambar 6) bertujuan membatasi nilai maksimal tegangan yang akan disimpan capacitor bank $\left(V_{\mathrm{C} 1}\right)$, dengan menggunakan suatu komparator. Terdapat tegangan referensi $\left(V_{\text {ref }}\right)$ yang bisa diatur pengguna, untuk dibandingkan dengan tegangan $V_{\mathrm{C} 1}$ yang sudah diturunkan (menjadi $V_{\mathrm{C}^{\prime}}{ }^{\prime}$ ) dengan faktor

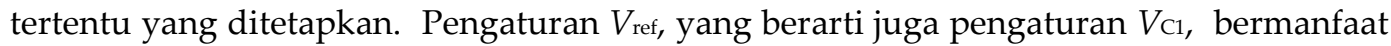
untuk menentukan nilai maksimal $V_{\mathrm{C} 1}$ yang berarti juga kekuatan tendang bola. Jika $V_{\text {ref }}$ mulai melebihi $V_{\mathrm{Cl}^{\prime}}$ maka keluaran rangkaian pembatas tegangan akan mendekati $0 \mathrm{~V}$ yang akan membuat transistor Q1 cut-“off" demikian pula MOSFET IRFP460. Dengan demikian nilai $V_{\mathrm{C} 1}$ tidak akan bertambah lagi. Diode $\mathrm{D}_{1}$ pada Gambar 4 dipasang untuk mencegah kapasitor $C_{1}$ mengosongkan tegangannya saat MOSFET “off”.

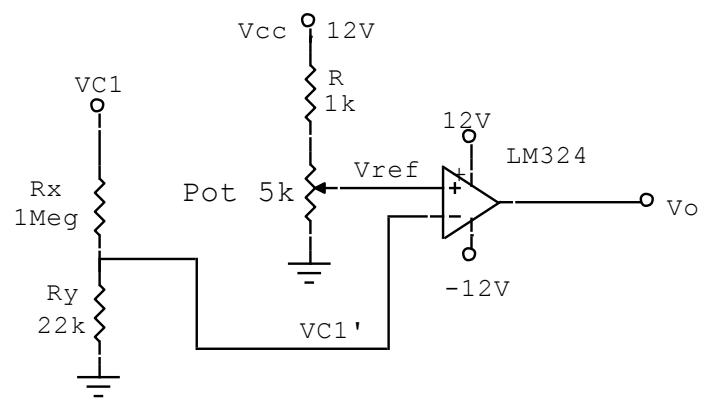

Gambar 6. Rangkaian pembatas tegangan menggunakan komparator

Pembagi tegangan Rx dan Ry berfungsi untuk menurunkan tegangan $\mathrm{V}_{\mathrm{C} 1}$ dari nilai maksimal yang terukur yaitu $440 \mathrm{~V}$ menjadi $10 \mathrm{~V}$. Nilai $\mathrm{R}_{7}$ harus jauh lebih kecil daripada nilai hambatan input dari LM324. Dengan menentukan nilai $R_{6}=1 \mathrm{M} \Omega$, maka nilai resistansi dari $R_{7}$ dapat dihitung dengan rumus sebagai berikut.

$$
R_{7} \approx \frac{10 \times R_{6}}{440} \approx 23 \mathrm{k} \Omega
$$

Nilai $R_{7}$ tersebut masih jauh lebih kecil daripada hambatan input dari LM324 yang bernilai di atas $1 \mathrm{M} \Omega$ sehingga memenuhi syarat.

\subsubsection{Rangkaian Pemicu Tendangan}

Untuk dapat melepaskan energi yang telah ditampung pada capacitor bank sehingga tendangan dapat dilakukan, maka dibutuhkan rangkaian yang akan menentukan kapan arus bisa melalui solenoid. Pada makalah ini, digunakan komponen SCR, yang ketika mendapat sinyal dari mikrokontroler akan memicu pelepasan energi dari capacitor bank ke solenoid. Gambar 7 merupakan rangkaian yang direalisasikan.

\subsubsection{Rangkaian Pengosong Tegangan Capacitor Bank}

Rangkaian pengosong tegangan capacitor bank (gambar 8) merupakan rangkaian proteksi, karena tegangannya yang tinggi, yang perlu dikosongkan pada saat robot akan diperbaiki maupun sekedar untuk dipindahkan setelah perlombaan selesai. Sebenarnya merujuk Rangkaian pengosong tegangan capacitor bank dibuat ditunjukkan pada Gambar 8 di bawah ini. Pada saat Vcc=12V (baterai terpasang pada robot) maka transistor 2N2222 saturasi sehingga MOSFET IRF840 cut off. Namun bila robot akan diperbaiki atau dipindah dan baterai dilepas maka Vcc=0V, transistor $2 \mathrm{~N} 2222$ cut off, diode zener Dz akan bertegangan 12V yang cukup untuk membuat MOSFET IRF840 “on" sehingga tegangan 
capacitor bank, $V_{\mathrm{C} 1}$, akan dikosongkan melalui $R_{\mathrm{D}}$ menuju ground. Tegangan kapasitor akan habis setelah $5 \tau=5 \times 20 \mathrm{k} \times 2240 \mu=224 \mathrm{~s}$ atau sekitar 3,7 menit.

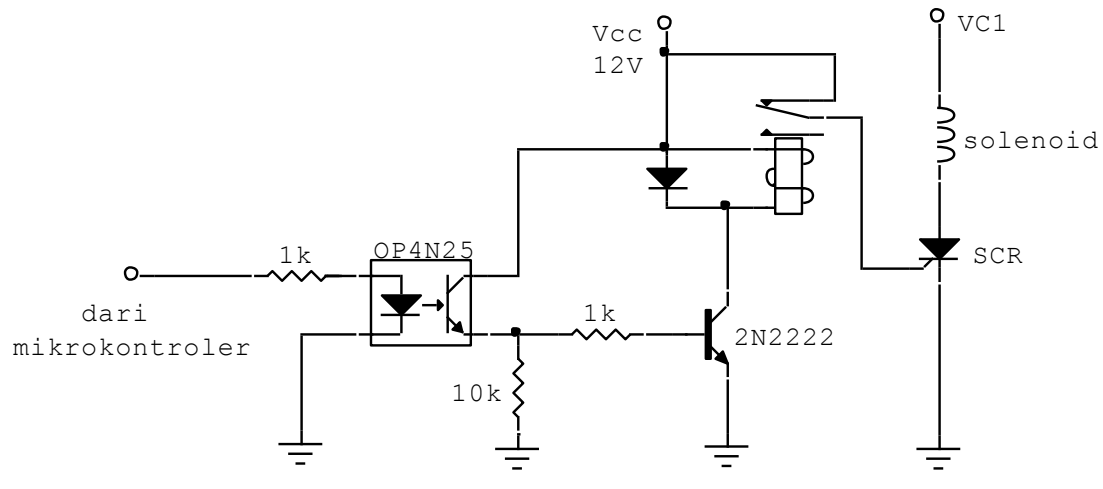

Gambar 7. Rangkaian pemicu tendangan

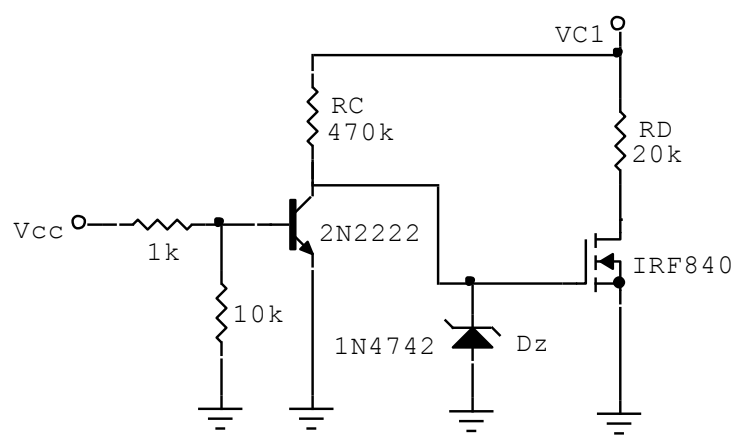

Gambar 8. Rangkaian pengosong tegangan capacitor bank

\section{Pengujian dan Pembahasan}

\subsection{Pengujian Rangkaian Penaik Tegangan}

Pengujian rangkaian $D C$ to $D C$ booster dilakukan dengan mengukur durasi waktu yang dibutuhkan dalam mengisi capacitor bank dari keadaan kosong atau 0V ke tegangan yang dituju. Pada pengujian ini, digunakan sebuah osiloskop sebagai alat ukur tegangan dan waktu pengisian. Hasil pengujian ditunjukkan Tabel 1. Berdasarkan Tabel 1, terlihat penurunan laju pengisian capacitor bank seiring dengan meningkatnya tegangan. Ini sesuai dengan persamaan pengisian kapasitor yang tegangannya akan naik secara eksponensial.

Tabel 1. Hasil pengujian waktu pengisian capacitor bank

\begin{tabular}{|c|c|c|}
\hline Vawal(V) & VC1(V) & Waktu(s) \\
\hline 0 & $50 \mathrm{~V}$ & 0,201 \\
\hline 0 & $100 \mathrm{~V}$ & 0,937 \\
\hline 0 & $150 \mathrm{~V}$ & 2,390 \\
\hline 0 & $200 \mathrm{~V}$ & 4,440 \\
\hline 0 & $250 \mathrm{~V}$ & 8,440 \\
\hline 0 & $300 \mathrm{~V}$ & 13,300 \\
\hline 0 & $350 \mathrm{~V}$ & 22,700 \\
\hline 0 & $400 \mathrm{~V}$ & 35,300 \\
\hline
\end{tabular}




\subsection{Pengujian Rangkaian Pembatas Tegangan}

Pengujian dilakukan untuk mencari selisih antara nilai tegangan $V_{\mathrm{C} 1}$ yang dikehendaki (atau dibatasi) oleh pengguna, yaitu $V_{\text {ref }}(1+\mathrm{R} \gamma / \mathrm{Rx})=46,5 V_{\text {ref }}($ Gambar 6), dibandingkan dengan nilai $V_{\mathrm{C} 1}$ yang benar-benar dicapai. Hasil pengujian ditunjukkan pada Tabel 2. Dari Tabel 2 terlihat bahwa ralat makin tinggi untuk tegangan yang makin besar. Namun tabel tersebut tetap bermanfaat bagi pengguna karena dapat memperkirakan berapa offset nilai $V_{\text {ref }}$ yang harus diberikan untuk mendapatkan batas tegangan $V_{c 1}$ yang dikehendaki.

Tabel 2. Hasil pengujian rangkaian pembatas tegangan

\begin{tabular}{|c|c|c|}
\hline$V_{\operatorname{ref}}\left(1+\mathrm{R}_{\gamma} / \mathrm{Rx}\right)$ & VC1 hasil pengukuran & Ralat \\
\hline $50 \mathrm{~V}$ & $49,4 \mathrm{~V}$ & $1,2 \%$ \\
\hline $100 \mathrm{~V}$ & $98,5 \mathrm{~V}$ & $1,5 \%$ \\
\hline $150 \mathrm{~V}$ & $146,9 \mathrm{~V}$ & $2 \%$ \\
\hline $200 \mathrm{~V}$ & $195,3 \mathrm{~V}$ & $2,35 \%$ \\
\hline $250 \mathrm{~V}$ & $239 \mathrm{~V}$ & $4,4 \%$ \\
\hline $300 \mathrm{~V}$ & $283,5 \mathrm{~V}$ & $5,5 \%$ \\
\hline $350 \mathrm{~V}$ & $325 \mathrm{~V}$ & $7,14 \%$ \\
\hline $400 \mathrm{~V}$ & $367 \mathrm{~V}$ & $8,25 \%$ \\
\hline
\end{tabular}

\subsection{Pengujian Laju Bola yang Ditendang}

Pada bagian ini, akan diuji laju bola yang ditendang dengan nilai $V_{\mathrm{C} 1}$ yang divariasikan, sehingga ketergantungan laju bola terhadap nilai $V_{\mathrm{C} 1}$ dapat diperkirakan. Alat yang digunakan untuk menguji adalah sebuah mikrokontroler Arduino Nano dengan dua buah sensor infrared obstacle detection dengan menggunakan fungsi interrupt dari mikrokontroler tersebut. Hasil pengujian ditampilkan pada Tabel 3. Berdasarkan pengujian tersebut diketahui laju maksimal bola yang dapat dicapai adalah 10,04m/s. Dengan menggunakan $V_{\mathrm{C} 1}$ sebesar $50 \mathrm{~V}$ ternyata bola masih diam (laju $0 \mathrm{~m} / \mathrm{s}$ ). Hal ini dikarenakan adanya gesekan antara plunger dengan cangkang solenoid.

Tabel 3. Hasil pengujian laju bola yang ditendan
\begin{tabular}{|c|c|}
\hline$V_{\mathrm{C} 1}$ & vbola $(\mathrm{m} / \mathrm{s})$ \\
\hline $50 \mathrm{~V}$ & 0 \\
\hline $100 \mathrm{~V}$ & 0,71 \\
\hline $150 \mathrm{~V}$ & 2,23 \\
\hline $200 \mathrm{~V}$ & 3,73 \\
\hline $250 \mathrm{~V}$ & 4,97 \\
\hline $300 \mathrm{~V}$ & 6,90 \\
\hline $350 \mathrm{~V}$ & 8,65 \\
\hline $400 \mathrm{~V}$ & 10,04 \\
\hline
\end{tabular}

\subsection{Pengujian Perulangan Tendangan dengan Selang Waktu 30 detik}

Pada bagian ini dilakukan pengujian untuk mengetahui laju bola yang ditendang oleh 10 kali tendangan dengan selang waktu antar tendangan 30s. Percobaan ini dimaksudkan untuk menguji apakah robot dapat menendang bola dengan baik setiap selang waktu 30s. Hasil pengujiannya ditunjukkan Tabel 4. Hasil pengujian menunjukkan laju rata-rata yang dihasilkan oleh mekanisme penendang bola pada saat melakukan tendangan berturutan adalah sebesar $9,77 \mathrm{~m} / \mathrm{s}$. 
Tabel 4. Hasil pengujian tendangan berturutan dengan selang waktu 30s

\begin{tabular}{|c|c|}
\hline Tendangan ke- & $\mathrm{V}_{\text {bola }}(\mathrm{m} / \mathrm{s})$ \\
\hline 1 & 10,00 \\
\hline 2 & 9,90 \\
\hline 3 & 10,20 \\
\hline 4 & 9,58 \\
\hline 5 & 10,23 \\
\hline 6 & 8,65 \\
\hline 7 & 10,13 \\
\hline 8 & 9,18 \\
\hline 9 & 9,89 \\
\hline 10 & 10,00 \\
\hline Rata-rata & 9,77 \\
\hline
\end{tabular}

\subsection{Pengujian Rangkaian Pengosong Tegangan Capacitor Bank}

Pada bagian ini dilakukan pengujian untuk menentukan nilai waktu yang dibutuhkan rangkaian pengosong tegangan capacitor bank untuk mengosongkan $V_{\mathrm{C} 1}$ dari nilai awal $\mathrm{r}$ $400 \mathrm{~V}$ ke nilai akhir 5V. Dalam pengujian ini digunakan sebuah stopwatch untuk mengukur waktu dan sebuah multimeter sebagai pengukur tegangan. Hasil pengujian ditunjukkan Tabel 5. Berdasarkan hasil pengujian tersebut didapatkan waktu yang dibutuhkan untuk mengosongkan tegangan capacitor bank dari 400V menjadi $5 \mathrm{~V}$ adalah rata-rata sebesar $224,7 \mathrm{~s}$, cukup dekat dengan perkiraan waktu yang telah dihitung pada bagian sebelumnya.

Tabel 5. Hasil pengujian waktu pengosongan tegangan capacitor bank

\begin{tabular}{|c|c|c|c|c|c|c|}
\hline \multirow{2}{*}{ VC1 } & \multicolumn{5}{|c|}{ Waktu(s) } & Rata-rata \\
\cline { 2 - 6 } & Percobaan 1 & Percobaan 2 & Percobaan 3 & Percobaan 4 & Percobaan 5 & \\
\hline 400V & 0 & 0 & 0 & 0 & 0 & 0 \\
\hline $350 \mathrm{~V}$ & 8,1 & 8,7 & 8,8 & 8,5 & 8,4 & 8,5 \\
\hline $300 \mathrm{~V}$ & 14,9 & 16,2 & 15,6 & 15,3 & 15,4 & 15,48 \\
\hline $250 \mathrm{~V}$ & 23,6 & 24 & 24 & 23,8 & 24 & 23,88 \\
\hline $200 \mathrm{~V}$ & 33,6 & 34,1 & 34,3 & 33,9 & 34 & 33,98 \\
\hline $150 \mathrm{~V}$ & 46,2 & 46,9 & 47,6 & 46,7 & 46,8 & 46,84 \\
\hline $100 \mathrm{~V}$ & 64,8 & 65,9 & 66,1 & 65,5 & 65,5 & 65,56 \\
\hline $50 \mathrm{~V}$ & 97,2 & 98 & 98,8 & 98,4 & 98,6 & 98,2 \\
\hline $5 \mathrm{~V}$ & 224,5 & 224,8 & 226,5 & 224 & 223,6 & 224,68 \\
\hline
\end{tabular}

\section{Kesimpulan}

Berdasarkan hasil realisasi dan pengujian alat dapat disimpulkan beberapa hal sebagai berikut ini.

1. Rangkaian penaik tegangan membutuhkan waktu sekitar 35,3s untuk meningkatkan tegangan capacitor bank $2240 \mu \mathrm{F}$ dari $0 \mathrm{~V}$ ke $400 \mathrm{~V}$.

2. Alat dapat menendang bola berdiameter $20 \mathrm{~cm}$ dan berat $400 \mathrm{gr}$ yang menghasilkan laju bola maksimal 10,04 m/s.

3. Setelah melakukan tendangan, dalam selang waktu 30s alat dapat melakukan tendangan kembali dengan laju bola maksimal sekitar 9,77 m/s.

4. Laju bola yang ditendang dapat diatur melalui sebuah potensiometer dengan rentang $0 \mathrm{~m} / \mathrm{s}$ hingga $10,04 \mathrm{~m} / \mathrm{s}$.

5. Alat dapat mengosongkan tegangan pada capacitor bank dari $400 \mathrm{~V}$ menjadi $5 \mathrm{~V}$ dengan waktu sekitar 224,7s. 


\section{Daftar Pustaka}

[1] S.H. Kasaei, S.M. Kasaei, S.A. Kasaei, “Design and Implementation Solenoid Based Kicking Mechanism for Soccer Robot Applied in Robocup-MSL," Internasional Journal of Advance Robotics Systems, vol.7, no.44, h. 69-76, 2010.

[2] I.K. Wibowo, M.B. Mochamad, T.U.A. Rizky, F.A. Rakhmat, A. Sholahuddin, P. Agung, M. Jauharul, T.R. Zanuar, "Rancang Bangun Mekanik Penendang Bola Pada Robot Soccer Beroda Menggunakan Solenoid," The $4^{\text {th }}$ Indonesian Symposium on Robot Soccer Competition, h. 17-21, 2016.

[3] M.S. Serafim, Ball Handling Mechanism for Mobile Robots, Thesis, Tecnico Lisboa, Oktober 2013.

[4] E. Rogers, "Understanding Boost Power Stages in Switchmode Power Supplies," Application Report, Maret 1999.

[5] Vishay Siliconix, IRFP460, SiHFP460 Power MOSFET, datasheet, Juli 2008

[6] Texas Instruments, LM555 Timer, datasheets, Januari 2015. 
